\title{
Does Credit Play a Role in Increasing the Yields of Wheat and Cotton:
} A Case Study of District Sahiwal

1 Muhammad Asim
2 Maqsood Hussain
3 Nasir Nadeem
2 Asghar Ali
2Muhammad Ali Imran
2 Mehran Hussain
2 Ihsan Jamil
2 Imran Ghaffar
${ }^{4}$ Muhammad Rashid
${ }^{2}$ Associate Professor, Assistant Professor, Research Officer, Research Associate, M.Sc Students respectively,
Institute of Agricultural and Resource Economics, University of Agriculture, Faisalabad (UAF)
${ }^{1}$ Assistant Professor, Sub Campus Burewala University of Agriculture, Faisalabad
${ }^{4}$ MS Agribusiness Student, IBMS, UAF

Doi:10.5901/mjss.2015.v6n4s3p482

\section{Abstract}

Agricultural credit plays a pivotal role in enhancing crop productivity by making possible easy access to essential inputs. The present study has been conducted during 2010-11 to investigate the effect of agricultural credit on wheat and cotton crops productivity in Sahiwal district. The data were collected from 100 farmers, among which half were loanee while the other half were non-loanee farmers. A Cobb Douglas production function was employed to assess the effect of various agronomic and production variables on productivity of wheat and cotton crops. The analysis estimated the coefficients of seed cost (scost), irrigation cost (ircost) and agricultural credit (dummy variable for credit) as 0.378, 0.098 and 0.026, respectively for wheat. All the variables were found to be highly significant for wheat crop. While in case of cotton, all variables except irrigation cost were significant at 1 percent while the variable of seed bed preparation was significant at 7 percent level of significance. Since agricultural credit has a significant role in enhancing the productivity of these crops, therefore, the study suggests of devising easy lending procedure, financing agricultural machinery on subsidized rates and creating the awareness regarding agricultural loans. These measures will enhance loan disbursement to farmers considered to be imperative for increasing productivity of wheat and cotton crops.

Keywords: Agricultural Credit, Agricultural Productivity, Cobb Douglass Production Function, Ioanee.

\section{Introduction}

Agriculture sector plays a very crucial role in the economy of Pakistan and 45 percent of the population in the country depends on agriculture, directly or indirectly. Agriculture contributes 21.4 percent to total GDP. Increase in agricultural production is necessary for food security and at the same time, qualitative perfection in rural societies is also imperative to face the emerging challenges of new millennium. The vision of a well-built and highly developed Pakistan could only be realized if the wealthy and progressive agriculture-base is visualized. To survive in this changing environment, we must switch over from traditional and subsistence agriculture system to a more market-oriented and scientific one. By this transformation, Pakistan can compete in the globalised and competitive world (GOP, 2014).

The credit to agriculture sector has a wide potential to make this sector more profitable, efficient and productive in 
less developing countries like Pakistan. One of the major problems in the adoptions of advanced technologies and effectiveness improvement in the sector of agriculture is unavailability or inaccessibility or capital constraint faced by the farmers. The lack of factors constraints was not only the possibilities to understand opportunities for enhancement in agriculture productivity but also the ability to constant consumption (Malik, 1999).

Agricultural credit consider as an essential element of the procedure of modernization of agriculture sector and commercialization of the rural community. Higher agriculture production was quickly achieved by easy and cheap credit to agriculture. So, it has been a most important policy of all the past and present governments to meet up the agricultural credit requirements of the farming economy of Pakistan. When credit to agriculture sector easily available farmers have more financial resources to purchase more inputs which ultimately result in higher production of agriculture sector. Credit availability and productivity growth of agriculture are positively associated with each other (Saeed at el., 1996). Formal/institutional credit has positive and highly significant impact on the production of agriculture sector in Pakistan (lqbal at el., 2003).

The credit market in Pakistan can be composed of two segments, i. e. the informal and formal credit sources. The informal/non institutional credit sources consist of middle man, brokers, friends, relatives, traders and commission agents etc. Pakistan Rural Household Survey (PRHS) 2001-02 shows that about 80 percent farmers got credit and out of that two-thirds farmers were those who acquired credit from informal sector, implying thereby that non-institutional agricultural credit is much more widespread in rural areas (Nasir, 2007). Now a day's formal/institutional credit sources well developed, expanded and also replaced many informal/non-institutional sources due to the successful completion of financial sector reforms which were undertaken in recent years (Bashir, 2006).

Currently, agriculture bank (ZTBL), Commercial Banks, Domestic Private Banks (DPBs), Federal Bank for Cooperatives is the financial institutions/formal credit sources in Pakistan and some national and international NonGovernment Organizations (NGOs) are also providing credit to agriculture sector for the development and welfare of the rural communities. Commercial banks are an important part of the formal credit sources which is quite common in now a day. Due to the importance of the agricultural credit, commercial banks have recently entered in this business with a huge amount of investment.

Currently almost twenty seven banks that are microfinance, Islamic and commercial banks have near about 3900 designated branches of agriculture are facilitating poor farmers by extending agriculture credit in Pakistan. Out of 27 banks 19 consist of commercial banks, 2 specialized banks, one Islamic bank and 5 microfinance banks. State Bank of Pakistan(SBP), keeping in view the increasing demand of credit has provisionally set an indicative agriculture credit disbursement target of Rs 315 billion during 2012-13 as against of Rs. 285 billion fixed during the last year (GOP, 2014).

Qureshi et al. 1984 found that during the last few years the former institutes of credit had become relatively more important and. According to them neglecting equitable distribution of credit as a policy tool for rural income redistribution may be a serious error by the policy-makers interested in an enhancement of rural equity.

Gadgil, 1992 indicated that farmers would pay more interest if the current interest rate loan process and other regulations have been deregulated. Such improvements in lending produced a large impact on employment and output. It also concluded that these modifications have not only improved the agricultural sector but also contributed to the growth of the lending institution. Ikram, 1994 concluded that the cropping intensity of loanee farmers was found to be higher as compared to the non-loanee farmers at all farm sizes. The cropping intensity in case of loanee farmers was 153.52 , 131.35 and 128.87 percent on small, medium and large farm sizes, respectively. The respective percentages for nonloanee farmers were calculated as 139.72, 112.03 and 102.64 percent. Karmakar, 1999 pointed out that one of the major problems facing traditional rural credit was the poor performance of the recovery mechanism.

Nazli, 2001 stressed that the provision of abundant and timely credit with effective monitoring was crucial for the improvement of agricultural. She added that in the absence of plentiful formal credit, small farmers and poor households have to rely on expensive informal credit.

Sheikh, 2001 stated that commercial bank' perception of low rate of recovery of loans obtained by the landless poor and small farmers was not correct. He suggested that loaning agencies should arrange training for the borrowers and supervise the utilization of credit.

Bashir, 2006 concluded that the agricultural credit impact significantly on the productivity of the wheat and sugarcane crop. This result emphasizes the importance of the agricultural credit in the presence of other major inputs like seed, fertilizer and irrigation. Tomasz, 2008 found that former credit had positive and highly significant impact on overall production of agriculture in developing country like India.

Abadullah et al. 2009 investigate the impact of agriculture credit on the livestock sector growth rate in the rural study areas by using stratified random sampling technique to collect the information about socioeconomic characteristics and input output values of respondents. He observed that economies of size exist in livestock sector due to credit 
availability. It increased the income of a family from livestock sector by 181 percent per month. The agriculture credit elasticity coefficient was 0.06 significant at 5 percent, literacy rate in term of schooling years and family size elasticity coefficients were 0.05 and 0.18 , respectively.

The present research made an attempt to achieve the following specific objectives;

1. To investigate the impact of agriculture credit in study area on the productivity of wheat and cotton crops.

2. To suggest policy measures based on the findings of the study.

\subsection{Research Methods}

A systematic approach has been used to conduct any analytical study and to make sure the importance, accuracy and significance of the study. District Sahiwal was selected as the study area for the present research. Total 10 villages were selected through random sampling technique which clearly represents the whole district. The present study was designed specially focusing on the role of agricultural credit on productivity of wheat and cotton crops. For the said purpose, the credit supplier in the study area was National Bank of Pakistan (NBP). NBP was selected due to the convenience in data collection as the principle author is an employee of NBP, Sahiwal branch. A list of the borrowers of the NBP was obtained from the respective branches for the selected villages. Five loanees and five non-loanees from each village were selected hence the total number of loanees and non-loanees selected were 50,50 for this study. Hence the total sample size was 100 for this research. To collect the relevant data that fulfill the study objectives, a comprehensive questionnaire was constructed and personal interviews were conducted in order to collect required information. The questionnaires were pretested in the field in order to validate the accuracy of the interview schedule. Multivariate regression analysis was employed to check the dependence of productivity of wheat and cotton crops on credit.

Two separate regression models were employed to investigate the impact of credit to agriculture sector particularly on these two crops (wheat and cotton).

Model 1) In wyield $=a_{0}+a_{1} \ln$ sbpcost $+\alpha_{2} \ln$ scost $+a_{3} \ln$ ircost $+\alpha_{4} \operatorname{lnppcost}+a_{5} \operatorname{lnf} \cos t+a_{6} \operatorname{loan}(d)+\mu_{1}$

In wyield $=$ natural $\log$ of the per acre wheat yield in mnds.

In sbpcost $=$ natural log of the per acre seed bed preparation cost.

In scost $=$ natural log of the per acre seed cost.

In ircost $=$ natural log of the per acre irrigation cost.

In ppcost $=$ natural log of per acre average plant protection cost.

In fcost $=$ natural log of per acre average fertilizer cost.

Loan $(\mathrm{d})=$ avail loan facility (dummy, $1=$ loan $\& 0=$ non loanee).

$a_{0}, a_{1}, a_{2}, a_{3}, a_{4}, a_{5}, a_{6}=$ are unknown parameters of model 1 which are to be estimated.

$\mu_{1}=$ disturbance term.

Model 2$)$ In cyield $=\theta_{0}+\theta_{1} \ln$ sbpcost $+\theta_{2} \ln$ scost $+\theta_{3} \ln$ ircost $+\theta_{4} \operatorname{lnppcost}+\theta_{5} \operatorname{lnfcost}+\theta_{6}$ loan $(d)+\mu_{1}$

In cyield $=$ natural $\log$ of the per acre cotton yield in mnds.

In sbpcost $=$ natural log of the per acre seed bed preparation cost.

In scost $=$ natural log of the per acre seed cost.

In ircost $=$ natural log of the per acre irrigation cost.

In ppcost $=$ natural log of per acre average plant protection cost.

In fcost $=$ natural log of per acre average fertilizer cost.

Loan $(\mathrm{d})=$ avail loan facility (dummy, $1=$ loan $\& 0=$ non loanee).

$\theta_{0}, \theta_{1}, \theta_{2}, \theta_{3}, \theta_{4}, \theta_{5}, \theta_{6}=$ are unknown parameters of model 1 which are to be estimated.

$\mu_{2}=$ disturbance term.

\section{Analysis Result}

\subsection{Regression Results for Wheat}

The coefficient of credit/loan is 0.026 which shows that one percent increase in loan increased the wheat yield by 2.6 percent. The coefficient of loan was also highly significant.

Table 1 shows the results of model 1. The estimated coefficient of the model represents the elasticities of production because Cobb Douglas production function was used in this study. The intercept coefficient of this model which represents the natural log of expected yield is -1.654 when all the inputs are considered zero. It is significant at 1 percent level of significance. The findings of research illustrated that all the coefficients have appropriate signs as per 
economic theory. The coefficients of seed, irrigation and fertilizer cost are significant, indicating that one percent increase in each variable increased per acre wheat yield by $0.378,0.098$ and 0.13 maunds, respectively. The coefficients of seed bed preparation cost and plant protection cost are insignificant. The reason may be either small sample size or lack of use of appropriate seed bed preparation techniques. The insignificant coefficient of plant protection cost is due to less use of pesticides as compared to cotton crop. The results explored that dummy variable has a significant impact on wheat yield. In other words farmers who have availed the opportunity of credit from commercial institutions have got 0.026 maunds of more wheat/ acre than non loanees. The result of this study also finds support form empirical literature e.g. Ikram, 1994, Nazli, 2001, Iqbal at el., 2003 and Bashir, 2006.

Table 1: Regression analysis of wheat crop (Model 1)

\begin{tabular}{|c|c|c|c|c|}
\hline \multirow{2}{*}{ Regression Analysis } & \multicolumn{2}{|c|}{ Coefficients } & \multirow{2}{*}{$\mathrm{t}$ stat } & \multirow{2}{*}{ Sig. } \\
\hline & A & Std. Error & & \\
\hline Constant & -1.654 & .785 & -2.109 & 0.011 \\
\hline Ln sbpcost & 0.37 & 0.379 & 0.976 & 0.389 \\
\hline Ln scost & .378 & .139 & 2.719 & 0.020 \\
\hline Ln ircost & 0.098 & .046 & 2.130 & 0.010 \\
\hline Ln ppcost & .033 & .023 & 1.452 & 0.149 \\
\hline Ln fcost & 0.13 & .045 & 2.888 & .000 \\
\hline loan (d) & .026 & .003 & 8.667 & .000 \\
\hline F-stat. & & & 46.67 & 0.000 \\
\hline
\end{tabular}

Source: Author's own calculations

F-statistics of first model shows the overall significance of the model. According to the research findings, the F-value was highly statistically significant (46.67). Estimated $\mathrm{R}^{2}$ was 0.693 which indicated that 69 percent variation in wheat yield was due to factors included in the model.

\subsection{Regression Results for Cotton Crop}

The results of multiple linear regressions for the cotton crop (model 2) are presented in the Table 2. The findings of the research showed that the all the variables had significant impact on cotton production. The signs of the explanatory variables were according to a priori expectations. Only the result of the irrigation cost on the cotton yield was insignificant at 13 percent level of significance. This may be due to the shortage of irrigation water. The most important finding was the impact of loan received by the farmers for cotton crop. The sign of the coefficient was positive with a value of 0.015 , demonstrated that farmers who have taken loan form commercial institutions have obtained 0.015 maunds more per acre cotton yield as compared to non loanees. Table 2 illustrates that the coefficient of seed bed preparation cost is 0.05 at a 1 percent significance level. It means that one percent increase in seed bed preparation increased 0.05 percent yield of cotton crop per acre. The value of the coefficients for plant protection and fertilizer cost were 0.021 and 0.18 , respectively which were highly statistically significant.

The F-value of this model was 26.99 which were highly significant and it illustrated that all the coefficients of the model are not zero simultaneously. The $\mathrm{R}^{2}$ value for this model was 0.612 which showed that 61 percent of the change in the cotton yield was due to explanatory variables included in the model.

Table 2: Regression analysis for cotton crop (Model 2)

\begin{tabular}{|c|c|c|c|c|}
\hline \multirow{2}{*}{ Regression Analysis } & \multicolumn{2}{|c|}{ Coefficients } & \multirow{2}{*}{ t stat } & \multirow{2}{*}{ Sig. } \\
\cline { 2 - 3 } & $\boldsymbol{\Theta}$ & Std. Error & & \\
\hline Constant & -0.30 & 0.500 & -0.60 & 0.550 \\
\hline Ln sbpcost & 0.050 & 0.020 & 2.50 & 0.012 \\
\hline Ln scost & 0.060 & 0.032 & 1.86 & 0.070 \\
\hline Ln ircost & 0.021 & 0.013 & 1.538 & 0.129 \\
\hline Ln ppcost & 0.111 & 0.033 & 3.29 & 0.000 \\
\hline Ln fcost & 0.18 & .020 & 4.21 & .000 \\
\hline loan (d) & 0.015 & 0.007 & 2.142 & 0.011 \\
\hline F-statistic & & & 26.99 & 0.000 \\
\hline
\end{tabular}

Source: Author's own calculations 


\section{Conclusions and Policy Recommendations}

The study concluded that credit to agriculture sector played a significant role in enhancing the productivity of both important crops (wheat and cotton) in study area. In the face of increasing cost of inputs and land preparation, the need for credit has increased manifold. It is, therefore, recommended that loan disbursement should be enhanced both by the commercial banks and Zari Tarqiati Bank Limited (ZTBL). The role of commercial banks is however, more important in the sense that these banks have their networks at gross root level. However, there is a need to simplify the procedure of sanctioning loan as majority of the farmers are illiterate. Moreover, interest rate is also needed to be lowered so that small farmers who constitute the major portion of the farming community could be able to take and use the loan for enhancing their agriculture productivity.

\section{References}

Abadullah., Mahmood, N., Khalid, M., And Kouser, S. (2009). The Role of Agricultural Credit in the Growth of Livestock Sector: A Case Study of Faisalabad. Pakistan Veterinary Journal, 29(2), 81-84.

Bashir, K. (2006). Role of Commercial Banks in the Development of Agriculture Sector of Pakistan: A Case Study of District Faisalabad. M. Sc. Thesis., Dept. of Development Economics., University of Agriculture, Faisalabad.

Gadgil, M. V. (1992). Future of Institutional Credit in India. Indian Journal of Agricultural Economics, 15, 52-57.

Government of Pakistan. (2014). Economic Survey of Pakistan 2013-14. Economic Advisor's Wing, Finance Division, Islamabad.

Ikram, M. T. (1994). An Evaluation of Supervised Credit Program of Agricultural Development Bank of Pakistan. M.Sc. Thesis, Dept. of Agricultural Economics, University of Agriculture, Faisalabad.

Iqbal, M., Ahmad, M., And Abbas, K. (2003). The Impact of Institutional Credit on Agricultural Production in Pakistan. The Pakistan Development Review, 4(II), 469-485.

Karmakar, K. G. (1999). Rural Credit and Self-Help Groups: Micro Finance Needs Concepts in India. Sage Publications, New Delhi, India.

Malik, S. J. (1999). Poverty and Rural Credit: The Case of Pakistan. Pakistan Institute of Development Economics,.

Nasir, J. (2007). Downside of Informal Agricultural Credit. Business, Daily Dawn Dated October 17. Http://Www.Dawn.Com/2007/10/ 17/Ebr13.Htm.

Nazli, H. (2001). Role of Micro-Credit in Economic Revival and Poverty Alleviation. Journal of Institute of Bankers, Research Report on Behalf of Pakistan Banking Council 1985.

Qureshi, S. K., Abbas, K., Siddiqui, A. N., And Ghani, E. (1984). Rural Credit and Rural Develoment: Some Issues. The Pakistan Development Review, 23, 273-282.

Saeed, Q., Nabi, I., And Faruqee, R. (1996). Rural Finance for Growth And Poverty Alleviation. International Food Policy Research Institute (IFPRI). Policy Research Working Paper No. 1593. Washington DC, USA.

Sheikh, R. A. (2001). Micro-Finance: The Most Effective Instrument in Poverty Alleviation. Pakistan Journal of Agricultural Economics, 1, 50-65.

Tomasz, S. (2008). Do Farm Credits Stimulate Development of Agriculture in Poland? Paper Presented at Congress of European Association of Agricultural Economists. 